\title{
Decision-making structures for successful management in Zimbabwe
}

\author{
Reinford Khumalo \\ Department of Business Management, University of Transkei - Butterworth Branch, Private Bag X3031, Butterworth \\ 4960 South Africa
}

Received November 1998

\begin{abstract}
This article discusses one of the management attributes discovered about Zimbabwe's most successful companies decision-making structures. Seven most successful companies from among those quoted on the Zimbawean Stock Exchange (ZSE) were selected in terms of financial and macroeconomic criteria in their industrial categories. The research for attributes was mainly qualitative - consisting of interviews of chief executives, departmental managers, skilled, semiskilled, and unskilled employees of the companies. The interviewees were also asked to complete a quantitative instrument, a semantic differential. Data from the interviews were content analysed. The findings showed that these companies have both centralised and decentralised decision-making structures that are in strata. The strata consist of those decisions that concern policy matters and are made at top management level and those at middle management level that take into account the input of the employees. This attribute has had some influence in the success of these companies and could thus contribute to the success of other less successful companies with a socio-economic situation similar to that of Zimbabwe's, the host country in which the study was conducted.
\end{abstract}

\section{Introduction}

The background of this study is that in recent years, businessmen in the West have expressed the need for excellence in the management of companies. The search for improvements has been brought about by rapid changes and challenges in the environment confronting the business community. Numerous businesses are experiencing an increased erosion of their traditional market shares from both foreign and domestic competition. Profit margins have decreased because of these and other factors (Cosier \& Dalton, 1986). It is for this reason that academics and others in Western countries sought innovative management approaches in an attempt to show the way those businesses could regain lost markets and profit margins to lay a good foundation for future development (Cosier \& Dalton, 1986). The study on excellent companies in Zimbabwe was also an attempt to offer the country's businesses some benefits similar to those sought by Western studies. It is extracted from research conducted to identify the management attributes that have made excellent Zimbabwean companies successful (Khumalo, 1997; 1998a; 1998b). A participative style of management is presented as one of the attributes contributing to excellence in Zimbabwean companies.

The objectives of the study were:

1. to find out how excellent Zimbabwean companies are managed;

2. to discover the distinctive management attributes of excellent Zimbabwean companies.

\section{Structure as an attribute of excellence}

Structure refers to the way an organisation is managed in terms of decision making. There are generally two commonly known structures: the centralised structure and the decentralised structure. A centralised structure implies that all key decisions are made by top management and this would mean that such decisions are made by head office in the case of a company with branches (Hobbs, 1987; Peters \& Waterman, 1982).

Companies striving for excellence are advised to build structures to which their employees can easily relate because this is essential in facilitating the adherence to a common philosophy. Consideration should be given to the likely effects of the structure on human relationships (Robson, 1986). The suggestion offered by Robson (1986) is that companies ought to have noticeable lines of communication because people relate more easily to such structures. This, however, does not mean that entire organisations should be built as family-sized autonomous groups. For the large organisation, it implies that small 'profit' or 'accountability' centres of up to 300 workers should be set up (Robson, 1986). Well arranged internal structures are the starting point of communicating with the customer.

According to Robson (1986), there should be a tendency towards decentralisation wherever possible for companies which want to achieve excellence and that would like to maintain such success. Centralised structures tend to focus on their own bureaucracies rather than giving full attention to the ultimate customer.

'Big centralised organisations often have massive staff sections, which generally speaking are most effective at frustrating and annoying the people in the line who do the productive work' (Robson, 1986: 29).

Although Robson does not elaborate on how centralised structures annoy people, the implication could be that urgent decisions that need to be made at the shop-floor level are often referred to top management for authorisation in enterprises with centralised structures. This could result in 
unnecessary delays. Structures should be such that as many people as possible are close to the end customer (Robson, 1986). Customer orientation and excellence go together. Robson (1986) brings a novel idea that the term 'customers' does not only refer to the people the company sells things to, that is the external customer, but also to everyone in the organisation who is and who has, a customer as a result of what he does. External customers are those who buy the company's products but internal customers are the company's employees. The internal customer is the person who receives the worker's portion of work after the worker has done his/her job. A worker is also a customer to someone who passes the work to him/her. Everyone in the organisation should look at this concept of customer orientation this way (Robson, 1986).

The internal customer is as important as the external customer. If this concept is properly understood and accepted by everyone in the organisation, the customers would receive the treatment, services and goods they need from the company because, generally, nobody wants to disappoint a customer. It is through the decentralised structure that this concept can easily be achieved (Robson, 1986). This view of an inclination towards decentralisation, however, differs from the findings by Peters \& Waterman (1982); and Hobbs (1987), who discovered that both centralised and decentralised organisational structures were prevalent among the successful companies they studied.

There has been some controversy during the last two decades on whether decentralisation or centralisation is the better organisational strategy. Quite a number of experts and business executives (such as Alfred Sloan \& Ralph Cordiner), consultants and academics, support either viewpoint (Hobbs, 1987). Even though the fourteen corporations studied by Hobbs showed an inclination towards decentralisation, several of them operated successfully for a considerable period of time under a centralised organisational structure (1987). Also the successful corporations studied by Peters \& Waterman (1982), were either decentralised or centralised.

Excellent companies are not characterised by a particular organisational structure. They are flexible (Peters \& Waterman, 1982; Hobbs, 1987). This attribute is an indication that excellent companies are not rigid in their styles of management. The companies are, however, very centralised on the values they most treasure (Peters \& Waterman, 1982). The type of structure followed is the one that suits the enterprise and is relevant to the situation. In these companies, some major decisions are left to the companies' branches or their departments. However, there are some key decisions which are central and reflect the companies' basic beliefs and values. Such decisions are made by head office (Khumalo, 1997; 1998a; 1998b).

\section{Methodology}

The focus of study in this research was industrial companies quoted on the ZSE. To facilitate an in-depth study, a sample of seven excellent companies was selected from the seven industry categories. The sample was drawn from a total of sixty companies quoted on the ZSE and it represents $12 \%$ of the total number.

Notably missing from the sample were mining companies. These were deliberately left out because the disposal of their products is largely controlled by international markets. The success or failure of a mining company may not be attributed to its management alone but also to other international factors such as the setting of the prices of mineral products by the international markets.

The sample design for the companies studied was purposive. The International Standard Industrial Classification (ISIC) was used for selecting the companies according to industry type so as to make the sample representative of the Zimbabwean Industry. An exfellent company was selected from each category of ISIC. A company could only be considered for selection as 'excellent' if it was competing with others in the same industry. The purpose of this process was to exclude monopolies from the study.

The companies studied were selected from the Financial Gazette, a Zimbabwean financial newspaper, which annually ranks all Zimbabwean companies quoted on the ZSE. Two sets of criteria were used in selecting the excellent companies.

The first set consisted of financial criteria that encompass those appreciated by Hitt \& Ireland (1987); Johnson, Natarajan \& Rapport (1985); and the critics of Peters \& Waterman (1982). They were:

a. Net earnings to turnover

b. Return on net asset value

c. Earnings per share

d. Market capitalization

The basis for the financial success of the companies studied was that they are in monopolistic competition and have the following features:

i. Each company faces a downward sloping demand curve.

ii. There is free entry into the industry.

iii. There is a large number of companies.

iv. Companies choose their prices as well as their outputs (Parkin, 1993).

These companies compete to raise their profits. The sources of gain in monopolistic competition include product innovation, that is constantly seeking products that provide the companies with a competitive edge. A company that manages to introduce a new and differentiated variety of products temporarily faces a downward sloping demand curve and will temporarily raise its price and therefore earn more profits. Advertising is one of the sources of gain of monopolistic companies (Parkin, 1993).

The measure of excellence was, therefore, the financial success of the companies. A successful company should be able to generate wealth for its shareholders (Peters \& Waterman, 1982). Such wealth is manifested in high profits earned by the companies.

The second set of criteria was based on the Zimbabwean government objectives including:

a. Growth in provision for local employment.

b. Growth in export performance. 
The government of Zimbabwe has interfered with the private sector since independence in 1980. According to Parkin (1993), all government economic action stems from two aspects of economic life:

i. market failure; and

ii. redistribution.

Market failure is the inability of an unregulated market to achieve allocative efficiency (Parkin, 1993). Goods and services must be equitably distributed to all citizens. The government tends to interfere with the private sector if it sees some failure by the latter in the proper distribution of goods and services.

The redistribution of income, wealth and resources is another explanation for government intervention. The government of a newly independent Zimbabwe redressed the imbalances created by the colonial rule by intervening in the private sector (Econmic Intelligence Unit - EIU, 1989-1990). The main focus of the government in its interventionist policy has been on employment and export performance (EIU, 1989-1990).

The criteria listed above were used to measure the companies for a period of seven years from 1988 to 1994 for the financial criteria and from 1988 to 1993 for the criteria based on economic conditions. Data for 1994 were not available for the latter type of criteria. The financial data for selecting the sample were derived from the data bank of the Stock Analysts Data World in Harare whilst the data for Macroeconomic criteria were collected from the Confederation of Zimbabwean Industries (CZI).

For a company to be selected as the best under the financial criteria, it had to be leading other companies in its category in at least three of the four financial criteria for a period of at least four years. For a company to be selected as excellent under the criteria based on macroeconomic objectives, it had to have the best results in at least one of the two measures for at least four of the six years.

Two instruments were used to collect data from the companies, an interview schedule for collecting data through the interviews and a questionnaire - a semantic differential.

Those interviewed were chief executives, departmental managers, skilled, semi-skilled and unskilled employees. Altogether 408 people was interyiewed.

The questions asked to elicit the decision-making structures of the companies were as follows:

1. What management style is used in the running of this company?

2. Do you feel encouraged to make suggestions affecting the overall policies of the company? Why?

3. Would you say that decision making in this company is centralised or decentralised? Why?

4. What decisions affecting your department do you have to refer to top management?

5. Do the employees have a way of suggesting any improvements on the way things are done in the company?

6. What style of management would you prefer to be used in this company?
7. Who makes major decisions in this company?

The second instrument, the semantic differential, was ob. tained from Prof Hofmeyr of the Graduate School of Business Leadership, Unisa. The statements given in the instrument to elicit responses from the interviewees are as shown in Table 1.

The two instruments, the interview schedule and the semantic differential, were tested through a pilot study of two companies in Butterworth, Transkei, and another company in Bulawayo, Zimbabwe. The content validity of the interview schedule was checked through presenting the questions to the interviewees to get feedback from them as to whether the questions were clear and understandable. The test of reliability on the other hand, was made on the quantitative instrument, the semantic differential, through the use of the reliability coefficient formula

$$
r_{n t}=\frac{v_{1}-v_{e}}{v t}
$$

The interviewees for the pilot study consisted of the chief executive officer, four departmental managers, and a $15 \%$ stratified proportional sample of employees from each of the levels of skilled, semi-skilled, and unskilled categories. The sample for the pilot study consisted of a total of 26 people. Titles of the departmental managers were written on pieces of paper and put into a small container. These pieces of paper with titles on them were picked and a title appearing on the piece of paper was written down and the paper replaced into the container until four titles were written down. This is sampling with replacement and it ensures that the papers picked have equal chances of being picked.

A reliability coefficient of 0.9708 was found for the semantic differential. This is a high score indicating that the instrument is reliable.

Interviewees for the main study were selected as follows: the employee interviewees were selected with the use of a stratified proportional sampling design. A rate of $18 \%$ was used for selecting employees from each of the stratum of skilled, semi-skilled, and unskilled employees. All the departmental managers in the companies were however, interviewed because the number of departments in most of the companies tended to be six or even less. Applying a pro-

Table 1 Semantic differential

\begin{tabular}{|c|c|c|}
\hline & Very Fairly Equally Fairly & Very \\
\hline Directive & & Participative \\
\hline Bureacratic & & Entrepreneurial \\
\hline Remote & & Involved \\
\hline Task oriented & & People oriented \\
\hline
\end{tabular}


portional sampling design in such small numbers would therefore, not result in a significant sample size.

The selection of employees was done by sampling with replacement and this was achieved by asking for a list of names of all the employees in the categories of skilled, semi-skilled and unskilled from the personnel office of each company. From the list, the names were written onto small pieces of paper by the researcher. The papers with the names were put into a container. The container was shaken, a piece of paper was picked from it at random, and the name on it written down. The piece of paper was returned to the container and the container shaken again and another piece of paper drawn and the name on it also added to the list of selected names. This procedure was repeated until the number of names was equal to the calculated proportion of $18 \%$ of the names in each category of skilled, semi-skilled or unskilled. No name was picked more than once.

Before the interviews began in each company, the company's mission statement, policies, company reports, and other available literature were asked for to be studied later by the researcher so as to get some background information about the companies, and for the purpose of comparing what was obtained from the interviews with the literature.

Some of the companies studied had branches in different parts of the country. The interviewees were drawn from either head office or from the branch. In some head offices only administrative work was done and there were, therefore, very few employees. In these instances it seemed more appropriate to research the branches. The assumption adopted by the researcher was that operations for the companies studied are standardised and that there is no significant difference between the employees of the branches and those of head office.

\section{Data analysis}

The responses from the interview schedule were content analysed and the unit of analysis used was the theme. The author looked for themes as he examined the transcribed data. The data was read over and over to establish the key thoughts. Any important ideas the author came across as he read the data were recorded. Emerging themes through conversation topics, recurring activities and meanings were identified. The author realised that determining the boundary of a theme was difficult and this could result in low inter-coder reliability. To minimise this limitation, the author employed the services of an editor who made an independent search for themes. The two independent findings were compared and reconciled to come up with the most relevant themes. The guiding principle for selecting the themes was that they meet the objectives of the study. In the discussion of the results, the companies were identified according to Table 1 as company number 1,2 or 3 , et cetera. The numbering began from the top of the table to the bottom, for example, company number 1 refers to PGI. This was the order in which the companies were studied.

The tool used to analyse data from the semantic differential was the Anova and the Duncan's Multiple Range Test for
Variability. The differences of the responses among skilled, semi-skilled and unskilled employees were measured. Also comparisons of company responses were made through the use of this instrument

The Anova is the most suitable analysis for a comparison among three or more variables. The values of the variables in the semantic differential ranged from 1 to 5 and were allocated as follows: Very $=1$; Fairly $=2$; Equally $=3$; Fairly $=4$; and Very $=5$.

The results were identified through the probabilities and the means indicated in Table 1 . If the probability shown in the last column of the table was less than 0.05 , the null hypothesis was rejected. It showed that there were differences at the $95 \%$ confidence interval between the different levels of respondents. Whereas, if the probability was greater than 0.05 , it showed that the null hypothesis had to be accepted because there was no significant difference between the responses of the different subjects.

Precautions surrounding this study concern three areas as follows:

1. Sample size.

2. Cause effect relationships.

3. Applicability to other organisations and the assurance of sustained extraordinary performance.

The sample size of the study is extremely small in relation to the multitude of no less than 561 companies of all sorts registered in Zimbabwe. Seven of that number represents only $0.015 \%$ of the total. The sample for this study, however, represents $12 \%$ of the companies quoted on the ZSE, the universe from which it was drawn. It is only companies quoted on the ZSE which were studied and those performing well were selected from each industry in accordance with the International Standard Industrial Classification Code (ISIC). Mining companies were excluded from the sample because they did not meet the free market criteria designed for the sample. The study has been exploratory and intensive; therefore, the sample size of $12 \%$ is adequate for the type of exercise applied in the study. The size of the sample for the study is also justified by the fact that the study is concerned with examining the best among many and only a few subjects possess such a quality.

No pretense is made by this study that all ingredients prerequisite to extraordinarily successful performance have been identified with respect to cause-effect relationships defined in terms of the financial criteria: return on net earnings to turnover, return on net asset value, earnings per share, market capitalisation, and the macroeconomic criteria: provision for local employment, and export performance. For that matter, no assertion can be made that all of the various characteristics found common among these seven companies are vital to continued success. Furthermore, it is possible that the eight management attributes discovered in the original study could have a synergistic effect - effecting successful performance as a result of their collective application. Singling out 'a participative style of management' as a management attribute to be implemented in a company could 
possibly not be as effective as applying all the eight characteristics simuttaneously.

However, the researcher is confident that this attribute - 'a participative style of management' discussed in this article reveals one of the reasons for the outstanding performance of the sampled seven companies. Furthermore, the researcher thinks that this attribute is applicable to a broad range of organisations, business-related or otherwise.

Although reasonably confident that the integration of this finding into less successful companies might enhance their financial and operating performance, the researcher is not keen to suggest precisely how it should be implemented and incorporated into an existing organisational arrangement. All corporate cultures contain an intricate network of parts and the slightest alteration of any dimension of which can create unanticipated reactions in other segments. Besides these caveats, the attribute identified in this study strongly suggests it can contribute to successful performance, and those managers ignoring its existence or relevance do so at some risk.

This study has been conducted exclusively on excellent companies and the prevailing structures of decision making discovered are common to all the companies studied regardless of industry category. The decision-making pattern of any other type of company could be the subject of further research. Also, because the manner of making decisions discovered in this study has been found to be practised by the excellent companies, the implementation of this technique by non-excellent performing enterprises both profit making and non-profit making to see if those companies would also perform well could be the subject of further research. Although the findings of the present study are on $\mathrm{Z}_{\text {r }}$ mbabwean excellent companies, they could benefit other companies in countries with a socio-economic situation similar to that of Zimbabwe.

\section{Results}

The theme that emerges from the responses of the interviewees revealed that although all the companies are de centralised geographically, with branches all over the country, decision making in these companies is both centralised and decentralised. Policy matters are decided upon at the companies' head offices and matters pertaining to the day-today operations are decided at branch level. Branches, for example, cannot set their own prices, and the authority to employ new staff has to be sought from head office. Employees give their input in the making of decisions at operational

\begin{tabular}{|c|c|c|c|c|c|c|c|c|c|c|}
\hline Position & $\mathbf{N}$ & Mean & Std Dev & Std Error & Min. & Max. & Var & $\mathbf{T}$ & DF & Prob. \\
\hline Management & 45 & 3.044 & 1.30 & 0.193 & 1 & 5 & Unequal & -0.33 & 56.3 & 0.738 \\
\hline Employees & 335 & 3.113 & 1.29 & 0.070 & 1 & 5 & Equal & -0.34 & 378.0 & 0.736 \\
\hline
\end{tabular}

For HO: Variances are equal, $F=1.02 ; \mathrm{DF}=(\mathbf{4 4 . 3 3 4}) ;$ Prob $>\mathrm{F}=0.8948$

\begin{tabular}{|c|c|c|c|c|c|}
\hline \multicolumn{6}{|c|}{ Customet oriented/accounting oriented } \\
\hline Source & DF & $\begin{array}{l}\text { Sum of } \\
\text { squares }\end{array}$ & $\begin{array}{l}\text { Mean } \\
\text { square }\end{array}$ & F value & $\operatorname{Pr}>\mathbf{F}$ \\
\hline Model & 5 & 6.68142706 & 1.33628541 & 1.12 & 0.3471 \\
\hline Error: & 369 & 438.71590628 & 1.18893200 & & \\
\hline \multirow[t]{3}{*}{ Corrected total } & 374 & 445.39733333 & - & - & \\
\hline & R-Square & c.v. & Root MSE & & V10 Mean \\
\hline & 0.015001 & 49.62295 & 1.09038158 & & 2.1973333 \\
\hline Source & DF & Type I SS & Mean square & F value & $\operatorname{Pr}>F$ \\
\hline COMP & 5 & 6.68142706 & 1.33628541 & 1.12 & 0.3471 \\
\hline Source & DF & Type III SS & Mean square & F value & $\operatorname{Pr}>F$ \\
\hline COMP & 5 & 6.68142706 & 1.33628541 & 1.12 & 0.3471 \\
\hline Number of means & 2 & 3 & 4 & 5 & 6 \\
\hline Critical range & .4295 & .4522 & .4673 & .4785 & .4872 \\
\hline
\end{tabular}


level and they are invariably involved in top management decisions through the works' council on matters that affect them such as working conditions. Only one out of the seven companies showed a tendency to centralise most of the decisions even those that affected the employees. This company, for example, did not have the office of personnel manager and employees of the company expressed concern that most of the matters affecting them were decided for them by top management.

The quantitative instrument could not specifically cover the measurement of a decision-making structure as the interview schedule did. This attribute could only be inferred from the responses of the instrument. Tables 2 to 5 show the quantitative results of the semantic differential.

According to the values in this variable, both management and employees perceived the management style of the companies to be equally directive and participative. The other values read from the semantic differential indicate that the management style of the companies is equally bureaucratic and entrepreneurial, fairly people oriented and customer oriented. There was also no significant difference among the responses of the companies.

The other attributes revealed by the semantic differential are that the companies are fairly people oriented and customer oriented. This characteristic also harmonises well with the finding that the employees in these companies participate in decision making at lower levels of the enterprises.

Concerning the variable inquiring whether the management style is bureaucratic or entrepreneurial, there is no significant difference among the three levels of positions of skilled, semi-skilled, and unskilled employees. The general response indicates that the management style of the companies is equally bureaucratic and equally entrepreneurial.

\begin{tabular}{cccc}
\hline Table 3b & & & \\
\hline Duncan grouping & Meaı & N & COMP \\
\hline A & 2.2762 & 105 & 1 \\
A & 2.2500 & 56 & 2 \\
A & 2.2414 & 29 & 6 \\
A & 2.2376 & 101 & 4 \\
A & 2.1944 & 36 & 5 \\
A, & 1.8542 & 48 & 7 \\
\hline
\end{tabular}

All the companies were perceived to be customer oriented in their management styles.

\section{Discussion}

When interviewed; the employees of all the seven companies responded that they participate in the making of some decisions of the companies through the workers' committees set up by a provision of the Labour Act 1980. In this stipulation, management and the workers' representatives meet at least once a month. Two sets of agenda, one from management and the other from the employees are discussed at these meetings. Matters often brought by management for discussion are such as the productivity levels to be achieved and the review of past performance. The employees, on the other hand, often bring those items pertaining to their welfare such as working conditions, wages and salaries. A people-oriented style of management implies that there is concern with the welfare of employees and the regard for them as a useful resource by the enterprise. This attribute is also demonstrated by the companies' involvement of employees in the decisions of matters affecting them.

\begin{tabular}{|c|c|c|c|c|c|}
\hline Source & DF & Sum of squares & Mean square & F value & $\operatorname{Pr}>F$ \\
\hline Model & 2 & 2.17506294 & 1.08753147 & 0.76 & 0.4687 \\
\hline Error & 332 & 475.42493706 & 1.43200282 & & \\
\hline \multirow[t]{3}{*}{ Corrected total } & 334 & 561.15223881 & & & \\
\hline & R-square & c.V. & Root MSE & & V2 mean \\
\hline & 0.004554 & 37.39573 & 1.19666320 & & 3.20000000 \\
\hline Source & DF & Type I SS & Mean square & F value & $\operatorname{Pr}>F$ \\
\hline POSITION & 2 & 2.17506294 & 1.08753147 & 0.76 & 0.4687 \\
\hline Source & DF & Type III SS & Mean square & F value & $\operatorname{Pr}>\mathbf{F}$ \\
\hline POSITION & 2 & 2.17506294 & 1.08753147 & 0.76 & 0.4687 \\
\hline \multicolumn{6}{|c|}{ Duncan's Multiple Range Test for Variable: V2 (Bureaucratic/Entrepreneurial) } \\
\hline \multicolumn{2}{|l|}{ Number of means } & & 2 & 3 & \\
\hline Critical Range & .3239 & .3410 & & & \\
\hline
\end{tabular}




\begin{tabular}{crl}
\hline \multicolumn{2}{l}{ Table 4b } \\
\hline \multicolumn{2}{l}{ Duncan grouping Mean } & N POSITION \\
\hline A & 3.3462 & 78 Skilled \\
A & 3.1591 & 132 Semi-skilled \\
A & 3.1520 & 125 Unskilled \\
\hline
\end{tabular}

The quantitative response that the companies are equally participative and equally directive in their management approach aptly describes the situation revealed by the interviews. Whilst the employees in these companies are involved in the making of decisions at lower levels of the organisations, it is only management that decides on key policy issues. The directive aspect of this management attribute could be explained by the fact that in these companies management demands performance from the employees. Although the employees are involved in setting production targets, management requires them to achieve such goals.

Employees and customers have often been closely linked together. In most cases, employees are regarded as internal customers (Clutterbuck \& Kernaghan, 1991; Robson, 1986). They are often the first point of contact by the external customer or client. Companies that show concern for their employees and have good relations with them are also likely to have good relations with their external customers. The concern for the customer could be exhibited by the decentralisation of some decisions to the employees - thus giving them a responsibility of initiating activities that would benefit the external customer. Such an exercise serves as an incentive to the workers (Clutterbuck \& Kernaghan, 1991).

Higher level decisions are, however, centralised. The main objective of the centralisation of decisions pertaining to policy matters is to ensure uniformity in all the branches; it is not based on power relations per se. Even though it is head office that decides on policy matters, branch managers are invariably asked to give their input. The centralisation of decision making on policy matters is, therefore, by agreement between branch management and head office. This approach is that of participatory management. To participate does not necessarily mean that one has to make the decision but that one is consulted before the final decision is made (Kroon, 1995). Centralisation, therefore, does not preclude participation.

The finding about the Zimbabwean companies was contrary to the suggestion by Robson (1986) who states that all the fourteen excellent companies he studied in the United States tended towards a decentralised decision-making structure. This implies that most major decisions were made at the branches without the necessity of consulting with head office. The disparity with Robson's (1986) finding on the decision-making structure is a matter of degree. Decisions on policy matters were also made at head office in the companies he studied. Although Peters \& Waterman (1982) do not specifically state the type of decisions that were decentralised at the enterprises they studied, they nevertheless mention that the purpose of this decentralisation is to 'liberate the human potential'. Lower levels of an organisation should be allowed to make major suggestions as this will encourage them to bring the best ideas to benefit the organisation.

It is clear to me that the centralisation of decisions concerning policy matters is standard practice of all organisations irrespective of their cultural background. One major reason for this procedure in all companies - Western or Zimbabwean - is for them to establish uniformity and to provide each subunit of the enterprise with the same benefits resulting from the decisions made by head office. That is obviated by the need to avoid contradictions within the same organisation.

The evidence of this study is also contrary to the suggestion by Montgomery: (in Blunt $\&$ Jones, 1992) that: (a) African organisations prefer centralised forms of decision making; (b) African managers are resistant to change; and (c) in Africa only appeals to higher authority can bring change.

That the authority for any major decision to be taken by the branches has to be approved by head office is consistent with the practice of maintaining uniformity as alluded to above. Branch management gets involved in the major decisions affecting them. They, however, have to motivate in order to cause this change. It is not that the decisions affecting the branches descend from top management without the ideas of the branch managers. There is constant communication between the branches and the head offices of these companies. Major decisions affecting the branches are made through consultation. These decisions, however, have to be made within the guidelines of company policy. The 'consultation' with head office required of the branches of the Zimbabwean excellent companies before making any major decision affecting them could be responsible for the difference between the companies studied by Peters \& Waterman (1982) and those presented in this study.

The suggestion by Montgomery (in Blunt \& Jones, 1992), may be confirmed partly if one considers the delays that occur in making decisions affecting the branches. One branch, for example, has had a shortage of staff for about three years, particularly during peak seasons, because it has no authority to increase its staff. To do so, it is required to get approval from head office. However, the reasons given by the branch manager were that: (a) the company had growth problems; (b) it had expanded very rapidly within the last five years; and (c) as a result of the above, it could not adequately staff all its branches within a short time. Some caution also had to be exercised by head office against over-spending on the budget. Therefore, the reasons for the delays in staffing have nothing to do with the dictatorial policies of these companies. The decisions affecting the branch are arrived at through consultation between the branch and head office (Khumalo, 1997).

The quantitative results also revealed that decision making in these companies is in strata. A noticeable difference between the decision making in Zimbabwean companies and the companies in Western countries is that whilst in both 
types of companies centralisation of decision making on key issues takes place, the chief executive in the West may decide alone whereas in the Zimbabwean set-up even centralised decisions are made through consensus by top management. No single individual makes all the decisions in these companies. This practice is an influence of the community concept of ubuntu which emphasises supportiveness, cooperation, and solidarity and it is the opposite of individualism (Dlomo, 1991; Khoza, 1993). Even though some studies have shown that there is no significant difference between black managers and white managers in the management approaches they use (Thomas \& Schonken, 1998: 70), findings about the Zimbabwean excellent companies tallied with the African philosophy of communalism. This could be because some management approaches are situational and they are amenable to predominating influences. The excellent $\mathrm{Zi}$ mbabwean companies are operating in an African nation and the African cultural practices prevail in these organisations. Noteworthy, also, is the fact that people's central values become internalised and tend to show up in their method of operation on any line of activity.

All the employees interviewed for this study stressed that the main decisions are made at the senior management level. It became clear to the author that workers' committees mainly serve the purpose of presenting the grievances of the workers to top management. They speak mainly on those matters affecting the workers. Whereas workers' committees serve to allay industrial conflicts, policy matters are exclusively the prerogative of top management. Although managers encourage participation of the employees on matters where employees can make a positive contribution, and although managers may listen to workers' recommendations on matters needing decisions, the managers themselves ultimately make the decision (O'Donnel \& Weihrich, 1992). This provision for dialogue and the resulting interaction between workers and management was favourably viewed by all the managers and executives interviewed for this study. The workers in these companies seem to understand their role in relation to that of the managers who after all are employed to make decisions.

There was no incident of a strike over the previous five years in all the companies studied. This could be attributed to the smooth relations resulting from the involvement of employees in the making of the decisions affecting them. This confirms the theory on participation that participation contributes to the success of the enterprise and creates harmony by enhancing motivation and yielding valuable knowledge through the exchange of information between employees and management (Lucas, 1978; O'Donnel \& Weihrich, 1992; Kroon, 1995; Leana, Ahlbrandt \& Murrel, 1992; Rafaeli, 1985; Wagner, 1994; Le Roux, Schmidt \& Scheepers, 1997). Involving workers in the organisation's decisions - especially those that directly affect them - serves as a confidence booster (O'Donnel \& Weihrich, 1992).
In the African context decision making is also in strata. According to Singh (1996), in the African community there is a council of elders which decides on matters pertaining to the community. Qualification into membership of this council is age and proficiency. The general belief among the African people is that wisdom derives from age. This category of decision makers gets input from the communities they represent and they make decisions through consensus at the highest levels. The deliberations of the elders are then communicated to the communities they represent (Singh, 1996; Teffo, 1996).

Translating this cultural metaphor to modern management, the elders could represent top management and the general folk who are represented at íraditional council deliberations represent the employees. This type of decision making, which is in strata and prevails in Zimbabwean excellent companies, is common in the culture of the African people and could have been influenced by it. Workers committees, which are established in accordance to the Labour Act 1980, also have concepts familiar with the African approach to decision making. It is thus manifest that Western management theories can be incorporated into the African culture to attain excellence in management.

\section{References}

Blunt, P. \& Jones, M. 1992. Managing organisations in Africa. New York: De Gruyter, 356p.

Cosier, R.A. \& Dalton, D. R. 1986. Search for excellence, learn from the Japanese - are these paneceas or problems? (Model of Organisational Evolution), Business Horizons, 29: 63- 68.

Clutterback \& Kernaghan, 1991. Making customers count: a guide to excellence in customer care. London: Mercurty Books.

Dlomo, 1991. One day seminar on incorporation of Ubuntu into a uniquely South African approach to management. Seminar of the Economic Convention of Southern Africa, Midrand 30/10/91.

Economic Intelligence Unit (EIU) 1989/90. Country profile Zimbabwe. London: Gower Street.

Hitt, M.A. \& Ireland R.D. 1987. Peters and Waterman revisited: the unended quest for excellence, Academy of Management Executive, 1(2): 91-98.

Hobbs, J.B. 1987. Corporate staying power: how America's most consistently successful corporations maintain exceptional performance. New York: Lexington Publishers, 178p.

Johnson, B., Natarajan, A. \& Rappaport, A. 1985. Shareholder returns and corporate excellnec, Journal of Business Strategy. $52-62$.

Khoza, R. 1993. The need for an Afrocentric management approach: a South African management approach; a contribution in African management: Philosophy, Concepts and Approach. Randburg: Knowledge Resources: 117-124.

Khumalo, R. 1997. A study of the management attributes of excellent companies in Zimbabwe. Unpublished doctoral thesis. Pretoria: Graduate School of Business Leadership, University of South Africa.

Khumalo, R. 1998a. Success in Africa, Productivity SA, 24(1): 2124.

Khumalo, R. 1998b. Zimbabwe's winning companies, Productivity $S A, 24(2): 32-33$. 
Koontz, H.. O'Donnel, C. \& Weihrich, H. 1986. Essentials of management, 4th ed. New York: McGraw-Hill Book Co., 564p.

Kroon, J. Ed. 1995. General management. Pretoria. Kagiso Tertiary, 506p.

Leana, C.R., Ahlbrandt, R.S. \& Murrel, A.J. 1992. The effects of employee involvement programs on unionized workers' attitudes. perceptions and preferences in decision making, Academy of Management Journal, 35(4): 861-873.

Le Roux, C.A., Schmidt, C.; Scheepers, J.M. 1997. Achieving motivation, locus of control and individuality as predictors of participative management in the South African educational environment, Journal of Industrial Psychology, 23(3): 1-8.

Montgomery. J.D. 1987. Probing managerial behaviour: image and reality in Southern Africa, World Development; 15(7): $911-929$ In Managing Organisations in Africa. Blunt, P. \& Jones, M. 1992. New York: De Gruyter, 356p.

O'Donnel C. \& Weihrich H. 1992. Essentials of management. 5th ed. New York: McGraw Hill Book Company, 518p.
Parkin, M. 1993. Macroeconomics. 2nd ed. New York: AddisonWesley Publishing Company, 597p.

Peters T. \& Waterman, R. 1982. In search of excellence. New York Harper \& Row, 360p.

Robson, M. 1986. The journey to excellence. Chichester: Wiley Publishers, 182p.

Singh, J.A. 1996. The concept of dharma in project management. A paper presented at the Workshop of Ubuntu Management at the Lesedi Cultural Village Honeydew, 27-28 June.

Thomas, A. \& Schonken, J.S. 1998. Culture-specific management and the African management movement - verifying the premises South African Journal of Business Management, 29(2): 67-76.

Teffo, L.J. 1996. Ubuntu a challenge to the corporate world in South Africa. A paper presented at the Workshop on Ubuntu Management, at the Lesedi Cultural Village, Honeydew, 27-28 June. 